\title{
Adsorption and Electrooxidation of Ethylene on Au Surfaces
}

\author{
C.F. Zinola ${ }^{1}$, and A.M. Castro Luna \\ ${ }^{1}$ Laboratorio de Electroquímica, Facultad de Ciencias, Tristan Narvaja 1674, \\ P.O.Box 10773, Montevideo, Uruguay \\ ${ }^{2}$ Instituto de Investigaciones Fisicoquímicas Teóricas y Aplicadas (INIFTA) Sucursal4, \\ Casilla de Correo 16 (1900) La Plata, Argentina
}

Received: June 30, 1996; November 19, 1996

\begin{abstract}
$\mathrm{O}$ comportamento eletroquímico na oxidação do etileno em superfícies de $\mathrm{Au}$ preferencialmente orientado é investigado em solução aquosa $1 \mathrm{M} \mathrm{H}_{2} \mathrm{SO}_{4}$ a $25^{\circ} \mathrm{C}$. Uma onda quadrada de potencial simétrica e periódica é aplicada a eletrodos policristalinos de Au para obter superfícies orientadas dos tipos (111), (110) e (100), as quais são caracterizadas por voltamogramas cíclicos e micrografias SEM. É comprovado que o etileno se adsorve em potenciais ligeiramente inferiores ao potencial de carga zero da interface $\mathrm{Au} / 1 \mathrm{M} \mathrm{H}_{2} \mathrm{SO}_{4}$, e dois resíduos são detectados num experimento de "stripping" anódico. A eletro-oxidação voltamétrica do etileno adsorvido e as curvas de polarização anódicas do etileno no meio da solução são medidas nas diferentes superfícies orientadas do Au.
\end{abstract}

The electrochemical behavior of ethylene electrooxidation on preferentially oriented $\mathrm{Au}$ surfaces is investigated in $1 \mathrm{M} \mathrm{H}_{2} \mathrm{SO}_{4}$ aqueous solution at $25^{\circ} \mathrm{C}$. A symmetric square wave periodic potential signal is applied to polycrystalline Au electrodes to obtain (111)-, (110)-, and (100)-type oriented surfaces, which are characterized by cyclic voltammograms and SEM micrographs. It is found that ethylene adsorbs at potentials just below the potential of zero charge of the $\mathrm{Au} / 1 \mathrm{M} \mathrm{H}_{2} \mathrm{SO}_{4}$ interface, and two residues are detected in an anodic stripping experiment. The adsorbed ethylene voltammetric electrooxidation, and the bulk ethylene anodic polarization curves are measured at the differently oriented Au surfaces.

Keywords: ethylene, $A u$, adsorption, oriented surfaces, oxidation

\section{Introduction}

Electrochemical oxidation of double and triple bonded organic substances on noble metals has been extensively studied in the last decades ${ }^{1-3}$. It is well known that $\mathrm{Au}$ polycrystalline electrodes have low electrocatalytic activity for the oxidation of saturated organic substances in acid solutions, but higher activity for unsaturated organic spe$\operatorname{cies}^{4,5}$.

It has not been clearly established whether ethylene adsorbs on Au before its electrooxidation. On the one hand, Weaver et $a l .{ }^{6}$ have presented experimental data obtained by SERS (Surface Enhancement Raman Spectroscopy) corresponding to $\mathrm{C}=\mathrm{C}$ stretching and symmetrical $=\mathrm{CH} 2$ bending bands for ethylene adsorption on rough $\mathrm{Au}$ electrodes. Adsorbed ethylene probably involves a $\mathrm{C}=\mathrm{C}$ bond parallel to the surface, with $\mathrm{CH}$ bonds tilting away from the surface. On the other hand, Pastor $e t$ al. ${ }^{7}$ have claimed that adsorbed ethylene at potentials from 0.2 to $0.8 \mathrm{~V}$ is rinsed away from the electrode by the base electrolyte in flux cell experiments. On-line DEMS (Differential Electrochemical Mass Spectrometry), together with in-situ FTIRS (Fourier Transform Infrared Spectroscopy) have been used to identify the ethylene electrooxidation products (ethanol, acethaldehyde, acetic acid, and carbon dioxide) at potentials higher than $0.8 \mathrm{~V} v s R H E$.

The surface properties of Au upon adsorption strongly depend on the metal crystallographic orientation ${ }^{8}$. Structural sensitivity to acetylene adsorbed species on Au single crystal surfaces has been found in acid media ${ }^{9}$, however there is no experimental data available for ethylene adsorbates on Au oriented surfaces. 

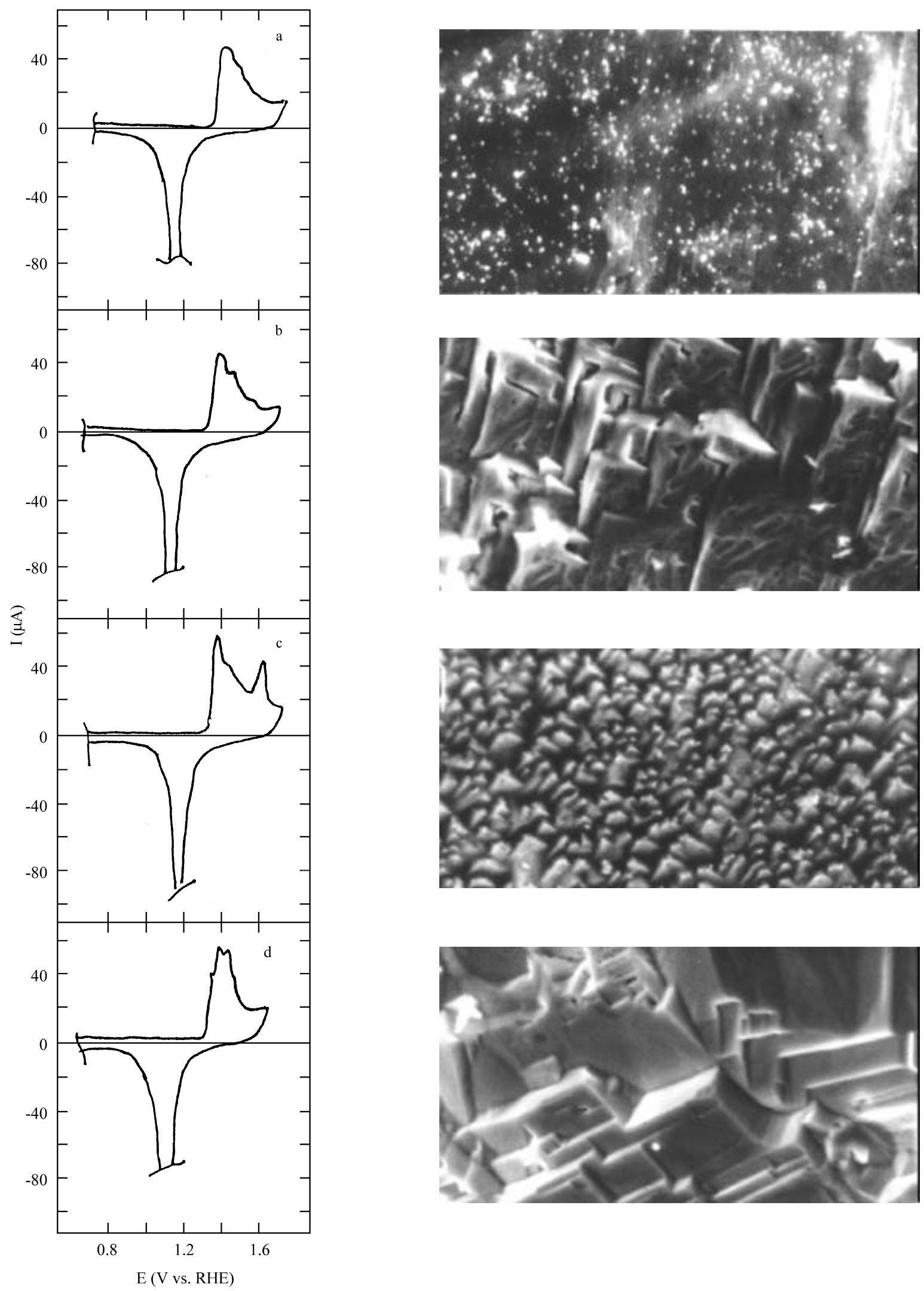

Figure 1. SEM micrographs, $5000 \mathrm{x}(0.1 \mu \mathrm{m})$, and cyclic voltammograms run at $0.1 \mathrm{~V} / \mathrm{s}$ in aqueous $1 \mathrm{M} \mathrm{H}_{2} \mathrm{SO}_{4}$ for: (a) $p c \mathrm{Au}$, (b) (100)-type Au, (c) (111)-type $\mathrm{Au}$, and (d) (110)-type $\mathrm{Au}$. 
The aim of this work is to study the ethylene adsorption on $\mathrm{Au}$ and the influence on the surface morphology on its adsorption and electrooxidation in acid media.

\section{Experimental}

Polycrystalline ( $p c$ ) and preferentially oriented $\mathrm{Au}$ (c.a. $0.2 \mathrm{~cm}^{2}$ real area) as working electrodes and a Au foil $\left(4 \mathrm{~cm}^{2}\right.$ geometric area) as the counter electrode were used.

All the potentials were referred to a reversible hydrogen electrode (RHE).

Preferentially oriented Au electrodes were prepared using a symmetric square wave potential signal (SSWPS) at frequencies covering the 2 to $12 \mathrm{kHz}$ range. The lower potential limit of the SSWPS was varied in the -0.2 to $0.5 \mathrm{~V}$ range, while the upper limit was held at $1.6 \mathrm{~V}$. In this way, (100)-, (110)-, and (111)-type preferentially oriented $\mathrm{Au}$ surfaces were obtained, depending on the experimental conditions ${ }^{10}$.

Cyclic voltammetric responses of the $\mathrm{O}$-adatom electrosorption process in the $0.0-1.7 \mathrm{~V}$ potential range in $1.0 \mathrm{M} \mathrm{H}_{2} \mathrm{SO}_{4}$ were used as fingerprints for the preferentially oriented $\mathrm{Au}$ surfaces. The characterization of the electrochemically oriented $\mathrm{Au}$ electrodes was complemented by Scanning Electron Microscopy (SEM) images.

Voltammetric and current transient measurements were performed in the working solution, i.e. ethylene saturated (ultra high purity, Matheson) $1.0 \mathrm{M} \mathrm{H}_{2} \mathrm{SO}_{4}$. Additionally, microflux cell adsorption experiments were made by holding the potential within the -0.3 to $0.5 \mathrm{~V}$ range for $10 \mathrm{~min}$ in the same solution. The current transient associated with ethylene adsorption was measured at each adsorption potential, and the anodic stripping voltammogram at $0.1 \mathrm{~V} / \mathrm{s}$ was run after replacing the solution with the base electrolyte. All the experiments were conducted at $25^{\circ} \mathrm{C}$.

\section{Results}

The potentiodynamic I/E profile of $p c$ Au run in $1 \mathrm{M} \mathrm{H}_{2}$ $\mathrm{SO}_{4}$ between 0 and $1.7 \mathrm{~V}$ at $0.1 \mathrm{~V} / \mathrm{s}$ is depicted in Fig. $1 \mathrm{a}$. The onset potential of the Au oxide begins at $1.35 \mathrm{~V}$, and the anodic profile shows three overlapping current peaks before the oxygen evolution reaction. A sharp oxide electroreduction peak is observed at c.a. $1.2 \mathrm{~V}$. On the right of Fig. 1a, the SEM micrography for $p c$ Au shows nonfaceted surface domains

\section{Electrode preparation}

After applying the SSWPS to a $p c$ Au wire between 0.1 and $1.6 \mathrm{~V}$ at $4 \mathrm{kHz}$ for $10 \mathrm{~min}$, a (100)-type Au orientation is developed (Fig. 1b). The corresponding cyclic voltammogram shows an anodic peak located at $1.43 \mathrm{~V}$ and a small second anodic peak at $1.52 \mathrm{~V}$. The corresponding SEM micrography shows spike-like stepped domains with square definition patterns.
A (111)-type $\mathrm{Au}$ surface results after applying the SSWPS to a $p c$ Au wire between -0.2 and $1.6 \mathrm{~V}$ at $12 \mathrm{kHz}$ during $15 \mathrm{~min}$. A cyclic voltammogram recorded subsequently afterwards shows three anodic peaks, at $1.42 \mathrm{~V}$, $1.52 \mathrm{~V}$, and a notably high peak located at $1.65 \mathrm{~V}$ (Fig. 1c). It is worth noting that the resulting preferentially oriented $\mathrm{Au}$ surface appears to be rather unstable upon potential cycling till $1.7 \mathrm{~V}$. The corresponding SEM micrography shows small crystallites with spike-like arrangements involving oriented tetrahedra.

Finally, when the SSWPS is applied to a $p c$ Au wire between 0.5 and $1.6 \mathrm{~V}$ at $2 \mathrm{kHz}$ for $10 \mathrm{~min}$, a faceted (110)-type Au surface is obtained. The corresponding cyclic voltammogram recorded at $0.1 \mathrm{~V} / \mathrm{s}$ (Fig. 1d) shows an anodic spike at c.a. $1.38 \mathrm{~V}$ and two distinguishable anodic peaks, one at $1.43 \mathrm{~V}$ and the other at $1.48 \mathrm{~V}$. The surface morphology examined by SEM exhibits a complex distribution of crystallites formed by rectangular steps.

\section{Ethylene adsorption and stripping}

Ethylene residues are detected after adsorption from ethylene saturated $1.0 \mathrm{M} \mathrm{H}_{2} \mathrm{SO}_{4}$ electrolytes at potentials lower than $0.2 \mathrm{~V}$, and no transient currents are recorded during ethylene adsorption. Figure 2 shows the anodic stripping voltammogram of the ethylene residue adsorbed for $10 \mathrm{~min}$ at $-0.1 \mathrm{~V}$ on a (110)-type Au electrode run at

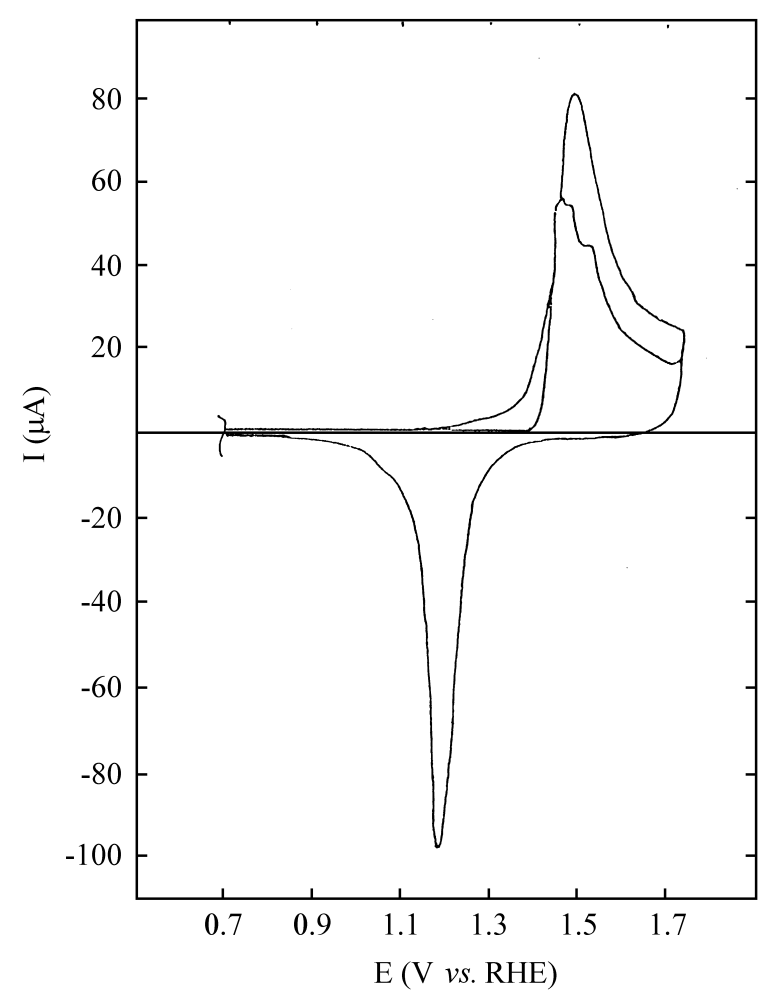

Figure 2. Anodic voltammetric stripping run at $0.1 \mathrm{~V} / \mathrm{s}$ of adsorbed ethylene on a (110)-type Au electrode in aqueous $1 \mathrm{M} \mathrm{H}_{2} \mathrm{SO}_{4}$; adsorption potential $-0.1 \mathrm{~V}$ and adsorption time $=10 \mathrm{~min}$. 
$0.1 \mathrm{~V} / \mathrm{s}$. The same adsorption experiment run in the base electrolyte shows negligible difference with respect to the repetitive voltammogram. The anodic stripping voltammograms of the ethylene residues are similar for the rest of the oriented Au surfaces examined.

The voltammetric electrooxidation of ethylene adsorbates on all of the Au surfaces at adsorption potentials lower than $0.2 \mathrm{~V}$, shows that two residues are formed namely RI and RII. The anodic stripping of RI is located in the double layer region just before the Au oxide formation, and the corresponding stripping for RII is in the entire potential domain of the stability of the Au oxide.

The charge densities associated with the anodic stripping of RI and RII show a quasi-parabolic potential dependence on all $\mathrm{Au}$ surfaces (Fig. 3). For adsorption potential values higher than $0.2 \mathrm{~V}$ noadsorbate is formed on
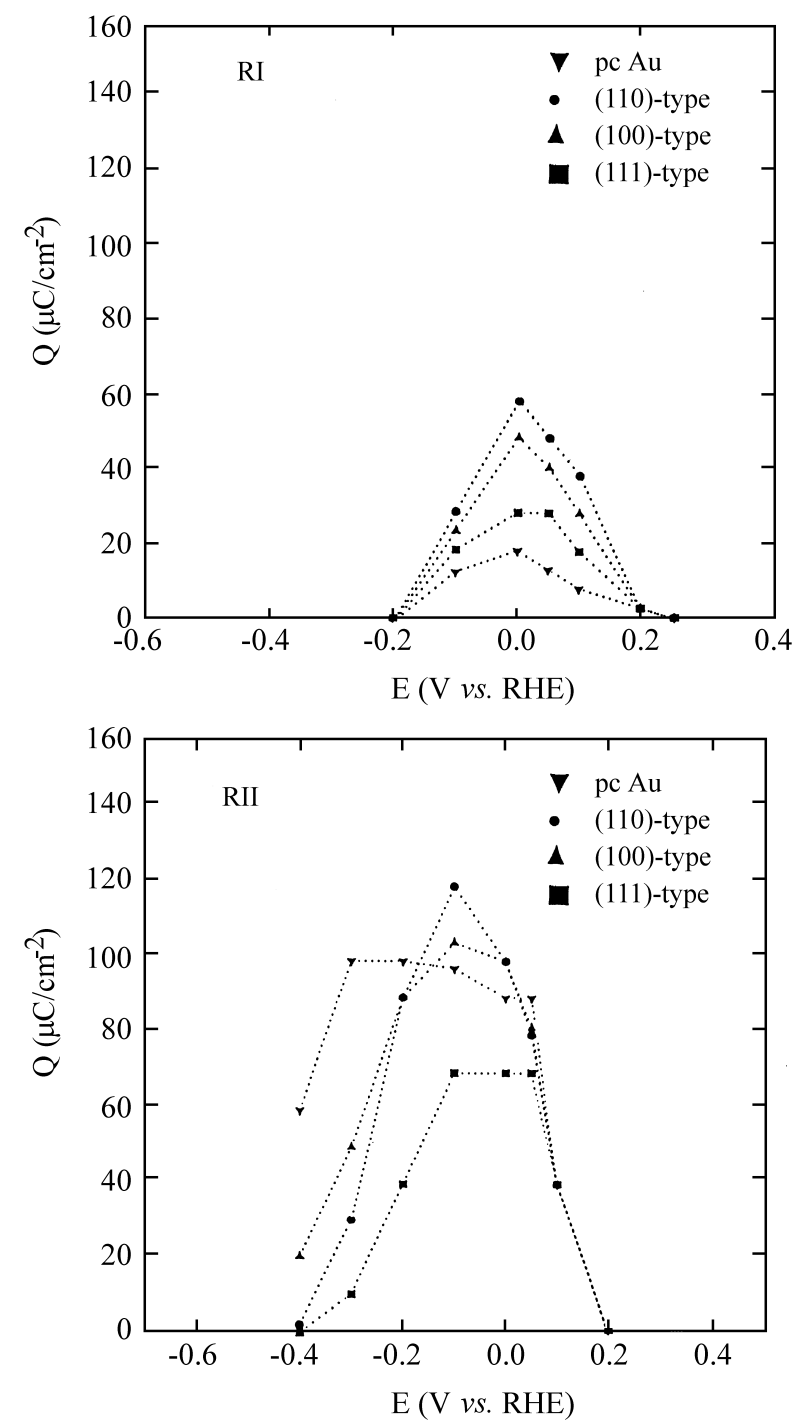

Figure 3. The potential dependence of the anodic charge density for adsorbed residues oxidized in RI and RII on the differently oriented Au surfaces in aqueous $1 \mathrm{M} \mathrm{H}_{2} \mathrm{SO}_{4}$.
$\mathrm{Au}$. It is worth noting that this value is placed in the neigborhood of the potential of zero charge (Epzc) of $p c$ $\mathrm{Au}$. The E $p z c$ of $p c \mathrm{Au}$ in sulfate-containing solutions is $c a$. $0.18 \mathrm{~V}^{11}$. Oxidation charge densities for ethylene adsorbed species are rather small, RII being almost twice as high as RI. The (111)-type Au surface exhibits the lower surface coverage values for the RII residue.

The independences of both residues is tested through a partial anodic stripping experiment. In this respect, $\mathbf{R I}$ is oxidized by an anodic scan to $1.3 \mathrm{~V}$; the subsequent anodic stripping till $1.7 \mathrm{~V}$ shows no RI residue and the same amount of charge for RII as that found in a total anodic stripping experiment. Thus, the adsorption of ethylene involves two different, independent adsorbates.

The existence of ethylene adsorbates on Au electrodes in neutral solutions has also been tested, and two types of adsorbates have been found ${ }^{12}$.

The effect of the preferentially oriented Au surface on ethylene adsorption and electrooxidation

The effect of the surface morphology was approached by employing preferentially oriented Au surfaces. Fig. 3 shows a comparison between the amount of adsorbed species (oxidation voltammetric charges), RI and RII, as a function of the adsorption potential on the different Au surfaces. It seems that trigonal plane atom arrangements do not favor ethylene adsorbates as either RI or RII.

Voltammetric bulk ethylene electrooxidation run at 0.1 $\mathrm{V} / \mathrm{s}$ on the different $p c$ and oriented surfaces shows a broad anodic peak extending from $0.9 \mathrm{~V}$ to the anodic evolution of oxygen. A maximum at ca. $1.3 \mathrm{~V}$ is observed just before the onset potential of the Au oxide. The splitting of the complex anodic profile can be achieved for lower scan rates.

Steady-state polarization experiments performed for ethylene electrooxidation on preferentially oriented $\mathrm{Au}$ surfaces lead to Tafel slope values of ca. $0.06 \mathrm{~V} /$ decade, independent of the surface morphology, though the current values are higher for (111)-type Au surfaces. It seems that he amount of adsorbed ethylene acts inhibiting the bulk ethylene electrooxidation process.

\section{Discussion}

The adsorption and oxidation of ethylene on metal substrates has been experimentally ${ }^{13,14}$ and theoretically ${ }^{15,16}$ studied, due to its application in electrosynthesis processes.

At the gas/solid interface, ethylene adsorption can be described by two different types of adsorbates, namely, a di- $\sigma$-bonded state where the carbon atoms are rehybridized towards the $\mathrm{sp}^{3}$ single $\mathrm{C}-\mathrm{C}$ bond lying perpendicular to the surface, and a $\pi$-bonded state where the molecule retains the $\mathrm{sp}^{2}$ hybridization with the double $\mathrm{C}=\mathrm{C}$ bond lying parallel to the surface ${ }^{17}$. Different parameters can affect the 
adsorption of ethylene on single crystal and $p c$ surfaces. Thus, the coadsorption of alkali atoms, such as potassium and cesium, at relatively low temperatures can change di- $\sigma$-species into $\pi$-bonded species ${ }^{14,18}$. This effect has been explained as an overpromotion of charge to adjacent metal atoms preventing the formation of more tightly bonded species such as di- $\sigma$-states. The response of the surface to alkali atoms is understood as an electron transfer from the alkali to the metal valence bands. This is combined with the electrostatic screening of the resultant positive charge by metal electrons. The relative amount of $\pi$-bonded species (weak adsorbates) and di- $\sigma$-species (strong adsorbates) in the presence of these alkali atoms has been detected by TDS (Thermal Desorption Spectroscopy) ${ }^{13}$ and UPS (Ultraviolet Photoelectron Spectroscopy $)^{17}$. Furthermore, the coadsorption of oxygen atoms also inhibits the formation of di- $\sigma$-species due to the withdrawal of charge from metal atoms ${ }^{13}$.

There is a lack of information about ethylene adsorption at the electrochemical interface, however, in-situ SERS provides evidence of ethylene adsorption. The analysis of the vibrational spectra shows bands at $1545 \mathrm{~cm}^{-1}$ and $1278 \mathrm{~cm}^{-1}$, respectively corresponding to the $\mathrm{C}=\mathrm{C}$ stretching and $=\mathrm{CH} 2$ bending modes on rough $\mathrm{Au}$ in acid media. The splitting of both signals is apparently due to adsorption at two energetically different surface sites. These bands, attributed to adsorbed ethylene, appear and disappear upon purging the solution with ethylene and argon, respectively ${ }^{6}$, showing a weak interaction with the $\mathrm{Au}$ surface.

However, it has to be emphasized that the formation of ethylene adsorbates was not found when flux cell experiments were performed, and only physisorption accounts for the interaction of the molecule with the Au surface in acid media at potentials higher than $0.2 \mathrm{~V}^{7}$.

Our results clearly show two adsorbed residues, RI and RII, that can be voltammetrically followed in an anodic stripping experiment. These residues are independently oxidized and the charge oxidation densities for both species have different contributions in the whole adsorption potential range. It is likely that ethylene adsorbed as $\sigma$ and $\pi$ species can be formed on the Au electrode, the influence of the electrode potential value being like that promoted by the coadsorption of alkali atoms in the gas / solid interface.

It is known that $\pi$ orbitals of an organic unsaturated adsorbate can donate a negative charge excess to metal $d$ orbitals, and a back donation from the metal orbitals to the $\pi$ antibonding orbitals of the molecule is accomplished. However, the negative charges given by the ethylene molecule to the $\mathrm{Au}$ atoms are not enough to achieve a chemisorption process at potentials higher than Epzc. Nevertheless, potentials lower than Epzc render a negative charge excess on the Au surface that can be donated to the $\mathrm{C}$ atoms of ethylene, preferentially yielding either di- $\sigma$-bonded-type adsorbates for adsorption potentials much lower than Epzc, or $\pi$-bonded-type adsorbates for adsorption potentials slightly lower than Epzc. On the other hand, the inhibition of ethylene adsorption at potentials higher than Epzc by specific anion adsorption cannot be neglected.

It is worth noting that adsorption of acetylene on $\mathrm{Au}^{9}$ gives similar anodic stripping profiles for residues at adsorption potentials higher than Epzc. In this respect, the negative charge excess donated by the acetylene molecule to the Au surface leads to a stronger bounded adsorbate than ethylene, but it seems that the nature of acetylenic residues is not very different from that of ethylene.

\section{Conclusions}

1) The adsorption of ethylene on $p c$ and preferentially oriented $\mathrm{Au}$ electrodes in aqueous $1 \mathrm{M} \mathrm{H}_{2} \mathrm{SO}_{4}$ takes place at potentials negative to the Epzc of the $\mathrm{Au} / 1 \mathrm{M} \mathrm{H}_{2} \mathrm{SO}_{4}$.

2) Ethylene adsorbed residues, RI and RII, are electrooxidized in the double layer region and in the Au oxide potential domain, respectively.

The anodic charge density involved in RII electrooxidation is twice as large as that in $\mathbf{R I}$.

3) Two types of ethylene adsorbates are postulated on Au surfaces, that is, di- $\sigma$-bonded and $\pi$-bonded species, the former being favored at negative potentials far from the Epzc of the $\mathrm{Au} / 1 \mathrm{M} \mathrm{H}_{2} \mathrm{SO}_{4}$.

4) $\mathrm{Au}$ (111)-type preferentially oriented electrodes exhibit a higher electrocatalytic activity for ethylene electrooxidation and lower amounts of RII adsorbates.

\section{Acknowledgments}

This work was financially supported by the Consejo Nacional de Investigaciones Científicas y Técnicas (CONICET) of Argentina. A.M.C.L. is member of the research career at the Comisión de Investigaciones Científicas de la Provincia de Buenos Aires, (CIC). C.F.Z. is a member of the Programa de Desarrollo de Ciencias Básicas (PEDECIBA), Uruguay.

\section{References}

1. Triaca, W.E.; Castro Luna, A.M.; Arvia, A.J. J. Electrochem. Soc. 1980, 127, 827.

2. Hubbard, A.T.; Young, M.A.; Schoeffel, J.A. J. Electroanal. Chem. 1980, 114, 273.

3. Schmiemann U.; Baltruschat, H. J. Electroanal. Chem. 1992, 340, 357. 
4. Damaskin, B.B.; Petrii, O.A.; Batrakov, V.V. In The Adsorption of Organic Compounds on Electrodes; Plenum Press, 1971.

5. Rosenhard, J.O.; Parsons, R.; Reeves, R.M. J. Electroanal. Chem. 1979, 96, 57.

6. Patterson, M.L.; Weaver, M.J. J. Phys. Chem. 1985, 89, 1331.

7. Schmidt, V.M.; Pastor, E. J. Electroanal. Chem. 1994, 376, 65.

8. Angerstein-Kozlowska, H.; Conway, B.E.; Hamelin, A.; Stoicoviciu, L. Electrochim. Acta 1986, 31, 1051.

9. Schmidt, V.; Stumper, J.; Schmidberger, J.; Pastor, E.; Hamelin, A. Surf. Sci. 1995, 335, 197.

10.Perdriel, C.L.; Arvia, A.J.; Ipohorski, M. J
Electroanal. Chem. 1987, 221, 229.

11. Perkin, R.S.; Livingstone, R.C.; Andersen, T.N.; Eyring, H. J. Phys. Chem. 1965, 69, 3329.

12. Castro Luna, A.M.; Zinola, C.F. To be published.

13. Cassuto, A.; Mane, M.; Jupille, J.; Tourillon, G.; Parent, Ph. J. Phys. Chem. 1992, 96, 5987.

14. Zhou, X.L.; Zhu, X.Y.; White, J.M. Surf. Sci. 1988, 193, 387.

15. Silvestre, J.; Hoffmann, R. Langmuir 1985, 1, 621.

16. Anderson, A.B.; Choe, S.J. J. Phys. Chem. 1989, 93, 6145.

17. Cassuto, A.; Mane, M.; Kronneberg, V.; Jupille, J. Surf. Sci. 1991, 251/252, 1133.

18. Cassuto, A.; Mane, M.; Hugenschmidt, M.; Dolle, P.; Jupille, J. Surf. Sci. 1990, 237, 63. 